\title{
PARAMETERS OF NUCLEAR MAGNETIC RESONANCE IN PATIENTS WITH CONGENITAL NARROWING OF THE LUMBAR SPINAL CANAL
}

\author{
PARÂMETROS DE RESSONÂNCIA MAGNÉTICA EM PACIENTES COM ESTREITAMENTO \\ CONGÊNITO DO CANAL VERTEBRAL LOMBAR \\ PARÁMETROS DE RESONANCIA MAGNÉTICA EN PACIENTES CON ESTRECHAMIENTO \\ CONGÉNITO DEL CONDUCTO LUMBAR
}

Eliu Hazael Morales-Rangel ${ }^{1}$, Fernando Espinoza-Chooue ${ }^{1}$, Alfredo Javier Moheno-Gallardo ${ }^{1}$, Luis Antonio Saavedra-Badillo ${ }^{1}$,

Eulalio Elizalde-Martínez ${ }^{1}$, Juan Carlos De la Fuente-Zuno ${ }^{1}$, José Manuel Pérez-Atanasio ${ }^{1}$

1. High Specialty Medical Unit (UMAE) “Dr. Victorio de la Fuente Narváez”, Distrito Federal, Mexico.

\begin{abstract}
Objective: To compare the morphological parameters of magnetic resonance in patients with congenital narrowing of the lumbar spinal canal with patients with low back pain. Methods: A descriptive, retrospective, observational study was conducted with measurements in the axial and sagittal magnetic resonance sections of the vertebral body and canal of the lumbar spine of 64 patients with diagnosis of low back pain, which were compared with resonance images taken from 31 Mexican patients with congenital narrowing of the lumbar spinal canal. Results: The results show that patients with congenital narrowing of the lumbar spinal canal in the axial sections have a difference in diameters, being L2 $<13.9 \mathrm{~mm}, \mathrm{~L} 3<13.3 \mathrm{~mm}, \mathrm{~L} 4<12.9 \mathrm{~mm}, \mathrm{~L} 5<13.1 \mathrm{~mm}$, compared with controls L2 $<20.5 \mathrm{~mm}$, L3<20.5 mm, $\mathrm{L} 4<19.3 \mathrm{~mm}, \mathrm{~L} 5<18.1 \mathrm{~mm}$ with $\mathrm{p}=0.000$. Conclusions: We found different measurements in the Mexican population compared to those found by similar studies. With the parameters obtained, it would be possible to make the proper diagnosis, surgical planning, and treatment.
\end{abstract}

Keywords: Low back pain; Magnetic resonance imaging; Lumbar vertebrae; Spinal stenosis; Anthropometry.

\section{RESUMO}

Objetivo: Comparar os parâmetros morfológicos de ressonância magnética de pacientes com estreitamento congênito do canal lombar com os pacientes com lombalgia. Métodos: Foi realizado um estudo descritivo, retrospectivo, observacional, com medições nos cortes axiais e sagitais de ressonância magnética do corpo e do canal vertebral da coluna lombar de 64 pacientes com diagnóstico de lombalgia, os quais foram comparados com ressonâncias feitas em 31 pacientes com diagnóstico de estreitamento congênito de canal vertebral lombar na população mexicana. Resultados: Os resultados obtidos mostram que os pacientes com estreitamento congênito do canal vertebral lombar apresentam, nos cortes axiais, uma diferença com relação aos diâmetros, sendo em L2 < 13,9 mm, L3 < $13,3 \mathrm{~mm}$, L4 < 12,9 mm, L5 < 13,1 mm, em comparação com os controles L2 <20,5 mm, L3 < 20,5 mm, L4<19,3 mm, L5 < 18,1 mm com $p=0,000$. Conclusões: Foram encontradas distintas medições na população mexicana em comparação com outros estudos similares. Com os parâmetros obtidos será possível realizar o diagnóstico adequado, planejamento cirúrgico e tratamento.

Descritores: Dor lombar; Imagem por ressonância magnética; Vértebras lombares; Estenose espinal; Antropometria.

\section{RESUMEN}

Objetivo: Comparar parámetros morfológicos en resonancia magnética nuclear de pacientes con estrechamiento congénito del conducto lumbar con pacientes con lumbalgia. Métodos: Se realizó un estudio descriptivo, retrospectivo, observacional, con mediciones en cortes axiales y sagitales del cuerpo y conducto vertebral en resonancias magnéticas de columna lumbar de 64 pacientes con diagnóstico de lumbalgia y se comparó con resonancias magnéticas de 31 pacientes diagnosticados con estrechamiento congénito del conducto lumbar en población mexicana. Resultados: Los resultados obtenidos demuestran que los pacientes con estenosis lumbar congénita presentan, en cortes axiales, una diferencia en cuanto a los diámetros, siendo en $L 2<13,9 \mathrm{~mm}, L 3<13,3 \mathrm{~mm}, L 4<12,9 \mathrm{~mm}, L 5<13,1 \mathrm{~mm}$ en comparación a los controles $L 2<20,5 \mathrm{~mm}, L 3<20,5 \mathrm{~mm}$, $L 4<19,3 \mathrm{~mm}, \mathrm{~L} 5<18,1 \mathrm{~mm}$ con una $p=0,000$. Conclusiones: Encontramos distintas mediciones en población mexicana comparado a otros estudios similares. Con estos parámetros obtenidos se podrá realizar un adecuado diagnóstico, planeación quirúrgica y tratamiento.

Descriptores: Dolor de la región lumbar; Imagen por resonancia magnética; Vértebras lumbares; Estenosis espinal; Antropometría.

\section{INTRODUCTION}

Spinal stenosis is a disorder that generates nerve compression in the spinal canal. ${ }^{1}$ One of the first descriptions was published by Arnoldi et al., ${ }^{2}$ who defined the pathology as any narrowing of the spinal canal, of the nerve roots, or of the vertebral foramen.

Spinal stenosis has been associated with various genetic changes, such as mutations in the COL9a2 gene, Trp2 and Trp3, which suggests that there are genetic factors that play an important role in the pathogenesis of this illness. . $^{3,45}$ These findings suggest that there is a genetic predisposition similar to that which occurs in intervertebral disc degnenraiton., 6

In a 2009 study by Kalichman et al., ${ }^{8}$ the prevalence of congenital and acquired lumbar stenosis was evaluated radiographically in 191 individuals, averaging 52.6 years of age and with an average BMl of 27.8, 
who had suffered at least one month of low back pain within a one year timeframe. Absolute congenital lumbar stenosis was observed in $2.6 \%$ of the population and acquired lumbar stenosis in $22 \%$ of the population, with no significant difference in terms of the sex of the population. ${ }^{8}$

One of the main studies to measure the lumbar spinal canal was conducted by Verbiest et al., 9,10 who proposed that two types of stenosis exist; absolute stenosis, in which the diameter of the spinal canal is less than $10 \mathrm{~mm}$, and relative stenosis, in which the canal measures between 10 and $12 \mathrm{~mm}$ in diameter. This study was conducted using intraoperative measurements. This same author conducted a study of the spine using computed axial tomography in which the diameters of the spinal canal in sagittal sections were measured, and he arrived at the conclusion that absolute stenosis is that in which the average sagittal anteroposterior diameter is less than $10 \mathrm{~mm}$ and when it is between 10 and $13 \mathrm{~mm}$ it is considered to be relative stenosis.

The author of this study refers to congenital stenosis as accounting for from 10 to $15 \%$ of all cases of lumbar stenosis. Usually idiopathic in nature, it involves a hypoplasia in the development of the posterior arch along with a shortening of the pedicles and a decrease in the anteroposterior diameter of the spinal canal. The central canal takes the form of a trefoil, better evaluated using an axial section. Some other less common causes may involve diseases with developmental changes such as achondroplasia, Morquio syndrome, and several other bone displasias. ${ }^{10}$

Ulrich et al. ${ }^{11}$ suggested that an anteroposterior spinal canal diameter of less than $11.5 \mathrm{~mm}$, measured in computed tomography sections, is abnormally small. Lee et al. ${ }^{12}$ reported that the sagittal diameter of the spinal canal in the lumbar spine should never be less than $10 \mathrm{~mm}$ in a normal spine. Schonstrom et al. ${ }^{13}$ introduced the term cross-sectional area of the dural sac, which measures the total area of the dural sac, and defined it as the most reliable measurable diagnostic parameter in lumbar stenosis. In this study, they reported that areas greater than $100 \mathrm{~mm}^{2}$ are considered to be normal, cross-sectional areas of the dural sac between 76 and $100 \mathrm{~mm}^{2}$ as moderately stenotic, and those less than $76 \mathrm{~mm}^{2}$ as severely stenotic.

In 2005, Singh et al. ${ }^{14}$ published a prospective study in which they used magnetic resonance imaging of the lumbar spine, as well as conventional lateral radiographs, to take specific measurements in patients diagnosed with congenital lumbar stenosis. In this study, axial sections of the anteroposterior diameter of the spinal cord of healthy patients were compared with those of patients with congenital stenosis, the latter group with a statistically significantly smaller diameter, averaging slightly less than $15 \mathrm{~mm}$. They concluded that patients with congenital stenosis, who have a smaller anteroposterior diameter of the spinal canal, a smaller length of the pedicle, and a smaller crosssectional area in axial sections than healthy patients, are predisposed to suffer symptoms at an earlier age.

More recent studies, like that by Kitab et al. ${ }^{15}$ published in 2014 , studied the radiographic anatomic variations through magnetic resonance of the spine in patients with lumbar stenosis who were less than 50 years of age and had presented symptoms for at least two months with neurogenic claudication. In their study, they found a reduction in the proportion of the cross-sectional area of the vertebral body to the spinal canal, as well as a reduction in the interlaminar angle and anteroposterior diameter of the spinal canal in patients with congenital lumbar stenosis.

Similarly, Cheung et al. ${ }^{16}$ conducted a cohort study in 2014 in which they evaluated which magnetic resonance radiographic criteria were clinically significant in patients with congenital lumbar stenosis and found certain radiographic parameters in patients who are more likely to develop symptoms of narrowing of the spinal canal at an earlier age.

Today, few studies exist that use imaging to quantitatively evaluate symptomatic patients with congenital lumbar stenosis. The importance of identifying the group of patients with lumbar stenosis rests in the fact that they present neurological symptoms at an earlier age than those with the degenerative counterpart. Thus, the approach to the patient with this pathology must be different and preoperative planning should consider multilevel surgery in treating a pathology that affects the entire lumbar spine.

\section{METHOD}

We conducted a retrospective observational study of 31 cases of patients younger than 50 years of age, diagnosed with congenital narrow lumbar spine canal, and who had undergone surgical treatment between January, 2014, and December, 2015, and 64 controls, younger than 64 years of age and diagnosed with low back pain, all from the Mexican population. The diagnoses were made by an experienced spine surgeon.

We measured the vertebral body and canal in axial and sagittal sections from T1- or T2-weighted magnetic resonances of the spine from L2 to L5. The following measurements were taken by two observers: the anteroposterior (AP) distance of the vertebral body in the axial section, the distance between the anterior and posterior cortices of the vertebral body, the width of the vertebral body in the axial section, the distance between the lateral cortices of the vertebral body, the AP distance of the vertebral canal in the axial section, the distance between the anterior and posterior cortices of the vertebral canal, the interfacetary distance of the vertebral canal in the axial section, the distance between the medial cortices of the vertebral canal at the level of the articular facet joints, the interlaminar angle in the axial section, the angulation formed by the direction of the vertebral laminae, the AP distance of the vertebral body in the sagittal section, the distance between the anterior and posterior cortical bones of the vertebral body, the height of the vertebral body in the sagittal section, the distance between the upper and lower platforms of the vertebral body, the AP distance of the spinal canal in the sagittal section, the distance between the posterior cortical bones of the vertebral body and the anterior cortical bone of the vertebral canal. This study was approved by the Institutional Review Board as registration number R-2016-3401-35.

\section{RESULTS}

The average age of the control group was 41.9 years (SD 10.3, ranging from $22-60$ years of age) while in the case group it was 42.1 years (SD 4.8, ranging from 28-49 years of age). There were 28 men and 36 women in the control group and 24 men and 7 women in the case group. A Kappa of 98 was used as the interobserver parameter.

The results as measured show that the average AP distance of the canal in the axial section in $\mathrm{L} 2$ in patients with congenital narrowing of the spinal canal was $13.9 \mathrm{~mm}$ (SD \pm 0.92 ) as compared to the controls at $20.5 \mathrm{~mm}$ (SD \pm 2.1$)$. In L3, it was $13.3 \mathrm{~mm}$ (SD \pm 0.73 ) as compared to $20.5 \mathrm{~mm}$ (SD \pm 2.0 ). In L4, it was $12.9 \mathrm{~mm}$ (SD \pm 0.93 ) as compared to $19.3 \mathrm{~mm}$ (SD \pm 0.93$)$. In L5, it was $13.1 \mathrm{~mm}(\mathrm{SD} \pm 1.0)$ as compared to $18.1 \mathrm{~mm}(\mathrm{SD} \pm 2.2)$.

The comparisons of the measurements taken are shown in Table 1 and Figure 1.

\section{DISCUSSION}

In our study, we found that there are variations in magnetic resonance measurements in the Mexican population as compared to other studies. According to Verbiest in the early $50 \mathrm{~s},{ }^{16}$ the critical values for absolute and relative stenosis are anteroposterior sagittal diameter of the vertebral canal of less than $10 \mathrm{~mm}$ and of between $10 \mathrm{~mm}$ and $12 \mathrm{~mm}$, respectively. Cheung et al. ${ }^{16}$ reported $14.7 \mathrm{~mm}$ for $L 2,13.8 \mathrm{~mm}$ for $L 3,13.7 \mathrm{~mm}$ for $L 4$, and $14.2 \mathrm{~mm}$ for $L 5$. In our results, we found differences in the diameters in the sagittal sections in the Mexican population: $12.3 \mathrm{~mm}$ for $\mathrm{L} 2,11.6 \mathrm{~mm}$ for $\mathrm{L} 3,12 \mathrm{~mm}$ for $L 4$, and $12.2 \mathrm{~mm}$ for $\mathrm{L} 5$

In 2005, Singh et al. ${ }^{14}$ published a prospective study in which they used magnetic resonance imaging of the lumbar spine, as well as conventional lateral radiographs, to take specific measurements in patients diagnosed with congenital lumbar stenosis. In this study, axial sections of the anteroposterior diameter of the spinal cord of healthy patients were compared with those of patients with congenital stenosis, the latter group with a statistically significantly smaller diameter, averaging slightly less than $15 \mathrm{~mm}$. In 2014, Cheung et al. ${ }^{16}$ conducted a similar study of magnetic resonance images. In their results, the anteroposterior diameter of the spinal canal in axial sections was $19.7 \mathrm{~mm}$ for $\mathrm{L} 2,19.2 \mathrm{~mm}$ for $\mathrm{L} 3,17.2 \mathrm{~mm}$ for $\mathrm{L} 4$, and $16 \mathrm{~mm}$ for $L 5$. Our measurements were $13.9 \mathrm{~mm}$ for $L 2,13.3 \mathrm{~mm}$ for $L 3,12.9 \mathrm{~mm}$ for $L 4$, 
Table 1. Comparison between cases and controls.

\begin{tabular}{|c|c|c|c|}
\hline Level & $\begin{array}{l}\text { Controls in } \mathrm{mm} \\
( \pm \mathrm{SD}) \text { except for the } \\
\text { interlaminar angle }\left(^{\circ}\right)\end{array}$ & $\begin{array}{l}\text { Cases in } \mathrm{mm}( \pm \mathrm{SD}) \\
\text { except for the } \\
\text { interlaminar angle }\left({ }^{\circ}\right)\end{array}$ & $\mathbf{p}$ \\
\hline \multicolumn{4}{|c|}{ Anteroposterior distance of the body in the axial section } \\
\hline L2 & $31.9(2.4)$ & $30.4(2.3)$ & 0.005 \\
\hline L3 & $32.5(2.2)$ & $31.1(2.4)$ & 0.008 \\
\hline L4 & $32.9(2.2)$ & $31.1(2.6)$ & 0.001 \\
\hline L5 & $32.5(2.9)$ & $31.1(2.1)$ & 0.017 \\
\hline \multicolumn{4}{|c|}{ Width of the body in the axial section } \\
\hline L2 & $45.9(3.3)$ & $41.3(2.9)$ & 0 \\
\hline L3 & $47.5(4.9)$ & $42.4(2.2)$ & 0 \\
\hline L4 & $49.3(3.0)$ & $42.7(2.5)$ & 0 \\
\hline L5 & $48.7(3.8)$ & $43.2(2.9)$ & 0 \\
\hline \multicolumn{4}{|c|}{ Anteroposterior distance of the canal in the axial section } \\
\hline L2 & $20.5(2.1)$ & $13.9(.92)$ & 0 \\
\hline L3 & $20.5(2.0)$ & $13.3(.73)$ & 0 \\
\hline L4 & $19.3(2.2)$ & $12.9(.93)$ & 0 \\
\hline L5 & $18.1(2.2)$ & $13.1(1.0)$ & 0 \\
\hline \multicolumn{4}{|c|}{ Interfacetary distance of the canal in the axial section } \\
\hline L2 & $16.2(1.8)$ & $12.5(1.9)$ & 0 \\
\hline L3 & $16.1(2.0)$ & $11.8(1.4)$ & 0 \\
\hline $\mathrm{L} 4$ & $16.9(2.7)$ & $11.6(1.5)$ & 0 \\
\hline L5 & $20.1(3.0)$ & $11.8(1.8)$ & 0 \\
\hline \multicolumn{4}{|c|}{ Internal interlaminar angle in the axial section } \\
\hline $\mathrm{L} 2$ & $75.9(5.4)$ & $59.8(11.3)$ & 0 \\
\hline L3 & $72.1(6.6)$ & $56.7(9.6)$ & 0 \\
\hline L4 & $73.1(7.2)$ & $55.4(6.8)$ & 0 \\
\hline L5 & $79.7(10.2)$ & $54.6(7.0)$ & 0 \\
\hline \multicolumn{4}{|c|}{ Height of the body in the sagittal section } \\
\hline L2 & $24.6(2.1)$ & $22(1.3)$ & 0 \\
\hline L3 & $25.2(2.3)$ & $22.8(2.5)$ & 0 \\
\hline L4 & $25.0(2.3)$ & $21.9(1.3)$ & 0 \\
\hline L5 & $25.3(7.9)$ & $21.7(1.5)$ & 0.014 \\
\hline \multicolumn{4}{|c|}{ Anteroposterior distance of the body in the sagittal section } \\
\hline $\mathrm{L} 2$ & $28.4(3.2)$ & $27.8(2)$ & 0.324 \\
\hline L3 & $29.5(2.6)$ & $25.5(1.8)$ & 0.061 \\
\hline L4 & $29.6(2.4)$ & $29.4(2.3)$ & 0.643 \\
\hline L5 & $28.7(2.8)$ & $28.3(3.6)$ & 0.593 \\
\hline \multicolumn{4}{|c|}{ Anteroposterior distance of the canal in the sagittal section } \\
\hline L2 & $16.4(1.2)$ & $12.3(1.2)$ & 0 \\
\hline L3 & $16.3(1.4)$ & $11.6(1.1)$ & 0 \\
\hline L4 & $16.5(1.5)$ & $12.0(1.5)$ & 0 \\
\hline L5 & $17.4(2.3)$ & $12.2(1.4)$ & 0 \\
\hline
\end{tabular}

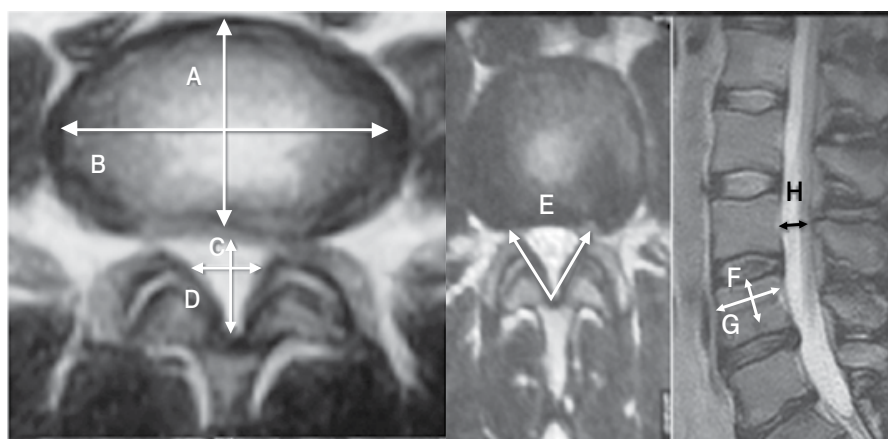

Figure 1. Radiological measurements. (A) AP distance of the vertebral body, (B) Width of the vertebral body, (C) AP distance of the vertebral canal, (D) Interfacetary distance of the vertebral canal, (E) Interlaminar angle, (F) Height of the vertebral body, $(\mathrm{G})$ Anteroposterior distance of the vertebral body, $(\mathrm{H})$ Anteroposterior distance of the vertebral canal.

and $13.1 \mathrm{~mm}$ for L5. A significant difference between populations was found when we compared the measurements of the canal diameter in axial sections of patients without lumbar stenosis in the Chinese population (L2 of $21.9 \mathrm{~mm}$, L3 of $22.4 \mathrm{~mm}$, L4 of $20.2 \mathrm{~mm}$, and L5 of $19.6 \mathrm{~m}$ ) with the same measures in the Mexican population ( $\mathrm{L} 2$ of 20.5 $\mathrm{mm}$, L3 of $20.5 \mathrm{~mm}$, L4 of $19.3 \mathrm{~mm}$, and L5 of $18.1 \mathrm{~mm}$ ).

Among the limitations of the study, we found that the sections of the magnetic resonances were at different levels of the vertebral bodies, but the section most suitable for our study was used. The cross-sectional area of the vertebral canal was not considered because the X-ray system used in the study did not have this function.

\section{CONCLUSIONS}

With this study, we can see differences between the measurements in the Mexican population compared to other similar studies with other populations worldwide. With the parameters obtained, we can make an adequate diagnosis, determine the lumbar level to be surgically treated, and identify the patients who are predisposed to suffer the symptoms of lumbar stenosis.

All the authors declare that there are no potential conflicts of interest regarding this article.

CONTRIBUTIONS OF THE AUTHORS: Each author made significant individual contributions to the development of the manuscript. MR, SB, and EC were the key contributors to the concept and the design of the research protocol and the manuscript. PA and MG contributed to the writing of the article and the critical review of the manuscript. MR, SB, and EC contributed to the collection and statistical analysis of the data. PA, EM, and DZ contributed to the review and final approval of the published version. All authors contributed to the conceptual design of the study.

\section{REFERENCES}

1. Moon MS, Kim SS, Sinn, JC. Lumbar spinal stenosis - a current view. Orthop Trauma. 2014:28(6):396-408.

2. Arnoldi CC, Brodsky AE, Cauchoix J, Crock HV, Dommisse GF, Edgar MA, et al. Lumbar spinal stenosis and nerve root entrapment syndromes. Definition and classification. Clin Orthop Relat Res. 1976:(115):4-5.

3. Hyun SJ, Park BG, Rhim SC, Bae CW, Lee JK, Roh SW, et al. A haplotype at the COL9A2 gene locus contributes to the genetic risk for lumbar spinal stenosis in the Korean population. Spine (Phila Pa 1976). 2011;36(16):1273-8.

4. Noponen-Hietala N, Kyllönen E, Männikkö M, Ilkko E, Karppinen J, Ott J, et al. Sequence variations in the collagen IX and XI genes are associated with degenerative lumbar spinal stenosis. Ann Rheum Dis. 2003;62(12):1208-14.

5. Sebastian A, Matsushita T, Kawanami A, Mackem S, Landreth GE, Murakami S. Genetic inactivation of ERK1 and ERK2 in chondrocytes promotes bone growth and enlarges the spinal canal. J Orthop Res. 2011;29(3):375-9

6. Aladin DM, Cheung KM, Chan D, Yee AF, Jim JJ, Luk KD, et al. Expression of the Trp2 allele of COL9A2 is associated with alterations in the mechanical properties of human intervertebral discs. Spine (Phila Pa 1976). 2007;32(25):2820-6.

7. Jim JJ, Noponen-Hietala N, Cheung KM, Ott J, Karppinen J, Sahraravand A, et al. The TRP2 allele of COL9A2 is an age-dependent risk factor for the development and severity intervertebral disc degeneration. Spine (Phila Pa 1976). 2005;30(24):2735-42.

8. Kalichman L, Cole R, Kim DH, Li L, Suri P, Guermazi A, et al. Spinal stenosis prevalence and association with symptoms: the Framingham Study. Spine J. 2009;9(7):545-50.

9. Verbiest H. Pathomorphologic aspects of developmental lumbar stenosis. Orthop Clin North Am. 1975;6(1):177-96

10. Verbiest $H$. The significance and principles of computerized axial tomography in idiopathic developmental stenosis of the bony lumbar vertebral canal. Spine (Phila Pa 1976). 1979;4(4):369-78

11. Ullrich CG, Binet EF, Sanecki MG, Kieffer SA. Quantitative assessment of the lumbar spinal canal by computed tomography. Radiology. 1980;134(1):137-43.

12. Lee BC, Kazam E, Newman AD. Computed tomography of the spine and spinal cord. Radiology. 1978;128(1):95-102

13. Schonstrom NS, Bolender NF, Spengler DM. The pathomorphology of spinal stenosis as seen on CT scans of the lumbar spine. Spine (Phila Pa 1976). 1985:10(9):806-11.

14. Singh K, Samartzis D, Vaccaro AR, Nassr A, Andersson GB, Yoon ST, et al. Congenital lumbar spinal stenosis: a prospective, control-matched, cohort radiographic analysis. Spine J. 2005:5(6):615-22

15. Kitab SA, Alsulaiman AM, Benzel EC. Anatomic radiological variations in developmental lumbar spinal stenosis: a prospective, control-matched comparative analysis. Spine J. 2014;14(5):808-15.

16. Cheung JP, Samartzis $D$, Shigematsu $H$, Cheung KM. Defining clinically relevant values for developmental spinal stenosis: a large-scale magnetic resonance imaging study. Spine (Phila Pa 1976). 2014;39(13):1067-76 